\title{
Türkiye'de Odun Dışı Orman Ürünlerinin Yönetimi
}

Kenan OK ${ }^{D}$, Yusuf Ziya TENGIZ

Kadir Has Üniv. Kadir Has MYO, İstanbul

$\bowtie$ : yusuftengiz@khas.edu.tr

\section{ÖZET}

Odun dışı orman ürünleri, yeryüzünde doğal olarak bulunan ve odun hammaddesi dişında kalan özel ürünler veya hizmetlerdir. Bu ürünlerin bir bölümü, sahip olduğu yüksek talep nedeniyle kültüre alınmakta ve tarımsal faaliyetlerle üretilmektedir. Çay olarak içilen kekik, süs bitkisi olarak kullanılan çuha çiçeği Türkiye'de hem doğal alanlardan toplanan hem tarımsal üretimi yapılan bitkilere örnektir. Bununla birlikte, odun dışı orman ürünlerinin çoğunluğu halen doğadan toplanarak tüketilmektedir.

Türkiye yüksek biyolojik çeşitliliğin sağladığı avantajın bir sonucu olarak, odun dışı orman ürünleri alanında önemli bir kapasiteye sahiptir. Bununla birlikte, coğrafi konumu ve tarihi birikiminin bir sonucu olarak, Türkiye'deki insanların yabani bitkilerden geniş bir yararlanma deneyimi bulunmakta ve odun dışı orman ürünlerinden faydalanma çeşitliliği görülmektedir. Bu üstünlüklere rağmen odun dışı orman ürünlerinin sürdürülebilir yönetiminin, pek çok ülkede olduğu gibi, Türkiye'de de tamamen garanti altına alındığını söylemek güçtür.

Bu makalede, Türkiye'nin odun dışı orman ürünleri kapasitesi tanıtılmaktadır. Ülke idari yapısı içerisinde odun dışı orman ürünlerinin yönetiminden sorumlu kurumsal yapı açıklanmaktadır. Ülke planları içerisinde odun dışı orman ürünlerine verilen yer ile bu ürünlerden faydalanma biçimini düzenleyen mevzuat tanıtılmaktadır. Sonuç olarak, odun dışı orman ürünleri çeşitliliği anlaşılmış ve bu çeşitlilikten sorumlu bir örgüt yapısı ortaya konmuş olsa da, bu türlerin sürekliliğini sağlayabilecek planlama ve yönetim şeklinin halen tartışılır bir yapıda olduğu, özellikle türe özgü bilgi ve yönetim süreçleri konusunda eksikliklerin bulunduğu anlaşllmaktadır.

\section{Management of Non-wood Forest Products in Turkey}

\section{ABSTRACT}

Non-wood forest products are specific goods or services which are considered as out of wood raw materials found in nature. Some of the products are cultivated because of their high demand and produced with agricultural practices. Thyme used in herbal teas and primrose used widely as an ornamental plant are significant examples of plants both collected from nature and have agricultural production in Turkey. However, most of the non-wood forest products are still consumed by collecting them from nature.

Turkey has a great capacity on non-wood forest products due to the advantage provided by high biodiversity. Additionally, people in Turkey has a wide range of experience on the utilization of wild plants and there is a significant diversity of use of non-wood forest products as a result of geographical location and historical heritage. Despite these advantages, it is difficult to mention that sustainable management of non-wood forest products is totally guaranteed in Turkey, as is the case in many other countries.
DOI:10.18016/ ksudobil.342303

\section{Makale Tarihçesi}

Geliş Tarihi : 08.10.2017

Kabul tarihi : 05.12.2017

\section{Anahtar Kelimeler}

Odun dışı orman ürünleri, Türk ormancılığı,

Kurumsal yapı, Orman yönetim planları

\section{Derleme Makale}

Article History

Received : 08.10.2017

Accepted : 05.12.2017

\section{Keywords}

Non-Wood Forest Products, Turkish Forestry, Institutional structure, Forest Management Plans

\section{Review Article}


The capacity of non-wood forest products in Turkey was introduced in this study. Institutional structure responsible for the management of non-wood forest products has been explained. The place of non-wood forest products in country plans and legislations regulating the ways of utilizing them were presented. As a result, although richness of non-wood forest products have been discovered and an institutional structure responsible for the diversity of these products have already been established, it was found that a way of planning and management structure ensuring the sustainability for the diversity of these species is still contentious, while there are deficiencies on the species-specific information and management processes.

To Cite : Ok K, Tengiz YZ 2018. Türkiye'de Odun Dışı Orman Ürünlerinin Yönetimi. KSÜ Tarim ve Doğa Derg 21(3). 457-471. DOI:10.18016/ ksudobil.342303

\section{GíRİ̧̧}

Türkiye; 1990-2015 döneminde orman alanını artırmayı başarmış 22 ülkeden biridir (FAO, 2016). Düzenli bir orman envanterinin ilk defa tamamlandığı 1973 yılında Türkiye orman alanı 20.199.296 ha düzeyindeyken, 2015 yılında 22.342.935 ha seviyesine yükselmiştir. Odun üretimi ve kapalılık açısından bozuk ormanlarin tüm ormanlara oranı, 1973 - 2015 döneminde, \% 56,15'den \% 43,14'e gerilemiştir. Aynı dönemde Türkiye ormanlarının dikili serveti 935.512.150 $\mathrm{m}^{3}$ düzeyinden, 1.611.774.193 $\mathrm{m}^{3} \mathrm{e}$ çıkmıştır. Yıllık cari artım 28.063.205 m³'den $\left(1,389 \mathrm{~m}^{3}\right.$ $\left.\mathrm{ha}^{-1}\right), \quad 45.904 .083 \quad \mathrm{~m}^{3} \mathrm{e} \quad\left(2,054 \quad \mathrm{~m}^{3} \quad \mathrm{ha}^{-1}\right)$ doğru yükselmiştir (OGM, 2016).

Türkiye, orman varlığı kadar, ormanlarla ilişkili biyolojik çeşitlilik açısından da dikkat çeken bir ülkedir. Kültüre alınmış pek çok bitki türüyle, evcilleştirilmiş pek çok hayvan türünün yabani ataları Türkiye'de doğal olarak yetişir. Türkiye'de yaklaşık 3.000 tanesi bu bölgeye özgü 10.000'den fazla bitki türü, tahminen 192 iç su balık türü, 22 amfibi türü, 106 sürüngen türü, 450 kadar kuş türü ve 132 yabani memeli hayvan türü bulunur. Dünya yüz ölçümünün ancak \% 0,5’i kadar alana sahip Türkiye, yüzey ölçüsüne göre kendi payına düşebilecek oranın çok üstünde canlı türü çeşitliliğine sahiptir (Işık, 2014).

Türkiye'de orman alanının, kapalılığın, dikili servet veya artımın iyileşiyor olması, ülke ormancılığı açisından olumludur. Ancak, tek başına bu göstergelerdeki iyileşmeleri, ülke biyolojik çeşitliliğinin sürekliliğini teminat altına alabilen kanıtlar olarak kabul etmek güçtür. Ormanların kapalılığı artarken, tür çeşitliliğinin azalması, orman alanları genişlerken, bazı bitki çeşitlerinin yaşam alanlarının daralması gibi sonuçlar yaşanabilmektedir ve Türkiye'deki gelişimin biyolojik çeşitlilik açısından etkileri konusunda sağlam bulgular yaygın değildir.

$\mathrm{Bu}$ nedenle, özellikle odun dışı orman ürünü olarak adlandırılan ormancilık üretimlerinin, hem faydalanılan türün sürekliliği, hem diğer türlerle etkileşimlerinin dikkatle incelenmesi gereklidir. Bu bildirinin amacı, Türkiye'deki odun dışı orman ürünlerinden faydalanma düzenini tanıtmak ve olası iyileştirme olanaklarını tartışmaktır.

\section{Odun Dışı Orman Ürünleri Konusunda Kavramsal Yaklaşım}

Her ne kadar, orman denilince akla odun üretilen bir doğal varlık gelse de, insanlığın evrimi incelendiğinde, farklı mal ve hizmet üretimleri dikkat çekmektedir. Insanlığın toplayıcılık döneminde, ormanın barınma ve beslenme firsatları odun üretiminden daha öne çıkan ürün veya hizmetler olarak görülmüştür. Tarım devriminin ardından ormanların insanlara sunduğu beslenme firsatlarının önemi azalmış fakat yerleşik hayata geçişin hızlanmasıyla birlikte, ormanların ürettiği odun hammaddesi öne çıkmıştır. Endüstri devrimi oduna alternatif materyalleri yaygınlaştırırken, yeşil ekonomi anlayışının gelişimi tekrar bu materyali önemli bir kaynak haline getirmiştir. Üstelik dünyanın farklı noktalarındaki farklı sosyal grupların, halen insanlığın farklı evrimsel dönemlerini yaşıyor olması, ormanlardan beklentileri daha karmaşıklaştırmaktadır. Günümüz dünyası, ormanda hayvan avlayarak ailesini beslemeye çalışan insanlarla, bu hayvanları seyrederek manevi tatmin arayanları birlikte yaşatmaktadır.

Bütün bu gelişmeler neticesinde, günümüzde ormanın ürününün ne olduğu sorusunu sadece odun hammaddesi olarak yanıtlamak olanaksızdır. Türkiye'de; en fazla talep gördüğü, sosyal ve ekonomik hayatta en üst derecede önemli kabul edildiği için odun hammaddesi genellikle ana (asli) ürün olarak nitelenmişken; reçine, ıhlamur çiçeği, meşe palamudu vb. ürünler yan (tali) ürün (Bozkurt ve ark. 1982; OGM, 1987) olarak kabul edilmiştir. Ancak toplumsal gelişmeler, yere ve zamana göre söz konusu mal ve hizmetlerin göreli önem derecelerini sürekli değiştirmektedir. Günümüzde hangi ürünün ana, hangisinin yan ürün olduğu ayrımı genelleme yaparak tanımlanabilir olmaktan çıkmıştır. O nedenle bugün odunun dışında kalan fakat talebi olan mal ve hizmetleri "yan" ürün olarak kabul etmek doğru değildir (Ok ve ark. 2012). 
Orman ürünlerinin tanımlanması veya nitelendirilmesi konusunda benzer durum uluslararası yazında da görülebilir. Berkes ve Davidson-Hunt'a (2010) göre; geleneksel ekoloji bilgisi ve odun dışı orman ürünleri alanındaki evrim, kaynak yönetim paradigmalarını da değiştirmektedir. Eskiden tek bir plan ile ormanın ürettiği tüm mal ve hizmetleri yönetmek sorun değilken, günümüzde her orman parçasının sahip olduğu olanaklar ile ilişkili toplumsal talepleri uzlaştırmaya dayalı, çok aşamalı bir planlama yaklaşımı tercih edilmektedir (Ok, 2000). Bu yaklaşımda, öncelikle ormanın neresinden hangi amaçlarla faydalanılacağ bulgularına göre her amaç kendi içerisinde tekrar planlanmaktadır.

Yaşanan bu değişim, bir yandan odun dışı orman ürünleriyle ilgili daha fazla çalışmaya neden olurken, diğer yandan tanımlama, kavramlaştırma sorununu ortaya çıkarmıştır. Odunun dışında kalan bazı orman ürünlerini tanımlamak için; küçük orman ürünleri, (minor forest products), özel orman ürünleri (special forest products), alternatif orman ürünleri (alternative forest products) (Lynch ve Maclain, 2003) terimleri yanında, odun dışı orman ürünleri (nontimber nonwood forest products), botanik ürünler (botanical products) ve ikincil orman ürünleri (secondary forest products) (Vance ve ark. 2001) terimlerinin kullanıldığı görülmektedir.

Odun dışı orman ürünü terimi konusunda uzlaşıldığı düşünülse de, bu terimin içeriği hakkında ortak bir anlayışa erişildiğini söylemek güçtür. Nitekim Davidson-Hunt, Duchesne ve Zasada (2001) bu konudaki belirsizliğe işaret ettikleri çalışmalarında, odun dışı orman ürünlerini "odunun dışında kalan, tüketim amacı taşıyarak veya taşımadan insanlar için bir değer ifade eden, ormanlık mekanlarda farklı formlarda bulunabilen biyolojik organizmalar" olarak tanımlamaktadır. Vance ve ark. (2001) ise odun dışı orman ürünü denildiğinde "odunun dlşsında kalan, ormandan hasat edilen, bitki, liken, mantar ve diğer organizmalar" anlaşılır demektedir.

Bu iki tanımda da odun dışı ürünün bir organizma olduğu ifade edilerek, hayvanlar da kapsam içine alınsa da gösterilen örneklerde nedense hayvana dayalı ürünlere yer verilmemiştir. Bu saptamaya ek olarak, bir canlı organizma olmayan mineraller ile ormancılık hizmetlerinin odun dışı orman ürünü tanımı dışında kaldığı düşünülebilir. Oysa Birleşmiş Milletler, Gıda ve Tarım Örgütü FAO'nun Odun Dışı Orman Ürünleri Programı incelendiğinde, ormanlardan veya orman ağaçlarından elde edilen odunsu ürünler dışında kalan bitkisel mallar ile hayvansal ürünlerin birlikte kapsandığ 2001) görülmektedir.

Bitkisel, hayvansal kökenli odun dışı ürünlerle; ormanların mineral üretim yeteneklerini odun dışı orman ürünü kavramı altında görme yaklaşımı,
Türkiye'deki bazı çalışmalarda da benimsenmiştir. Örneğin Başkent ve Küçüker'e (2011) göre odun dışı orman ürünleri "ormandan elde edilen ve odunun dişında kalan, bitkisel, hayvani ve mineral ürünlerdir". Topay'a (2011) göre "rekreasyonel hizmetler de" önemli bir odun dışı orman ürünüdür.

Odun dışı orman ürünü tanımındaki farklılıklar, bu ürünlerin sinıflandırılmasında da farklılıklar yaratmaktadır. Davidson-Hunt ve ark. (2001) ile Mohammed (2001) ve Chamberlain'in (2004) çalışmaları birlikte değerlendirildiğinde;

a) Gıda ürünleri: meyveler, içkiler, temel yağlar, tatlandırıcılar, baharatlar, bal, şuruplar, karamelalar, tereyağları, mantarlar, tohumlar, çaylar, sebzeler

b) Malzemeler ve imalat ürünleri: yapışkanlar, alkol, mum, kumaş, boyalar, temel yağlar, kokular, tütsüler, lignosülfonat, reçine, dolgu materyalleri, ip ve halatlar, terebentin

c) Sağlık ve kişisel bakım ürünleri: aromatik yağlar, kozmetikler, ilaçlar, temel yağlar, bitkisel sağllk ürünleri, parfümler, kokular, hayvan bakım ürünleri, şampuanlar, sabunlar

d) Dekoratif ve estetik ürünler: yılbaşı ağaçları, kozalak ürünler, kabuk ürünler, ahşap el ürünleri, yontular, çiçek aranjmanları, çelenkler, doğal boyalar e) Çevresel ürünler: biyo-yakıtlar, biyo-pestisitler, geri dönüşüm ürünleri

f) Peyzaj ve bahçe ürünleri: peyzaj ağaçları, çalılar, yabani çiçekler, otlar, malçlar, toprak iyileştirme ürünleri şeklinde altı ayrı grupta sınıflandırmak olanaklıdır.

g) Tüketilmeyen odun dışı orman ürünleri: doğal ve kültürel mirasa dayalı turizm ve eğitim, biyolojik çeşitliliğin korunması, rekreasyon, su kalitesi,

şeklinde bir sınıflandırma ortaya çıkmaktadır. Yukarıdaki sınıflandırmadaki kapsam genişliği ve kavrama yüklenen zenginlik, Lund (1998) örneğinde görüldüğü gibi, bazı yazarların, Odun Dış Orman Kaynakları terimini önermelerine neden olmuştur. Gerçekten de, bazen bir mal, bir ürün veya hizmet şeklinde karşımıza çıkabilen bu değerleri bir kaynaklar bütünü olarak görmek daha doğru bir yaklaşımdır.

Odun dışı orman ürünleri, yerel kültür ve ekonomilerden (Sisak ve ark. 2015) tüm insanlığa doğru genişleyen bir refah etkisine (Shackleton, Pandey, 2014; Mukherjee, Chaturvedi, 2017) sahiptir. Odun dışı orman ürünlerinin sürdürülebilir yönetimi gıdadan ilaca, kozmetikten endüstriyel hammaddeye kadar uzanan pek çok alanda çalışanlara ve orman sahiplerine gelir getirme, ilişkili topluluklarda işlendirme yaratma özelliklerine sahiptir. $\mathrm{Bu}$ ürünlerle bağını koparan topluluklarda önemli oranda geleneksel bilgi ve kültürel kayılar yaşanmaktadır. Diğer yandan, Neves ve ark. (2015) belirttiği gibi, odun dışı orman ürünü üretimi amacıyla korunan alanlarda bozulmalar, tek türleşmeler veya tarımda yapısal 
değişimler ortaya çıkabilmektedir. Bu nedenle, odun dışı orman ürünlerinin dikkat çekici özelliğinin Türkiye'de ve Dünyada uzun süre devam edeceği görülmektedir.

Türkiye'nin Odun Dışı Orman Ürünleri Üretimi
Türkiye Ormancılık İstatistikleri 'ne (2016) göre 19882016 döneminde odun dışı orman ürünlerinden ağırlıkları temel alınarak yararlanılanlardan, yıllık 10 tondan fazla faydalanılan tür veya ürünler Çizelge 1'de gösterilmiştir.

Çizelge 1: 1988-2016 döneminde yılda ortalama 10 tondan fazla yararlanılan odun dışı orman ürünleri

\begin{tabular}{|c|c|}
\hline Yararlanılan Tür ve Ürünler & $\begin{array}{l}\text { Ortalama Üretim } \\
{\text { (Ton yll }{ }^{-1)}}\end{array}$ \\
\hline Muhtelif Çalılar, (Underbrush) & $11.391,236$ \\
\hline İşlenmemiş Defne yaprağı, (Laurus nobilis raw leaves) & $7.839,571$ \\
\hline Çrralı çam kök odunları, (Resinous wood) & $5.552,000$ \\
\hline Cirasız çam kök odunları, (Non-resinous wood) & $3.236,571$ \\
\hline İşlenmemiş Kekik, (Thymus spp. raw) & $2.245,077$ \\
\hline Fistıkçamı kozalağı, (Cone of semen pine) & $2.005,193$ \\
\hline Mersin yaprağı, (Folium myrti) & 614,571 \\
\hline Adaçayı, (Salvia sp.) & 468,815 \\
\hline Laden, (Cistus) & 453,167 \\
\hline Keçiboynuzu (harnup) meyvesi, (Carob) & 311,353 \\
\hline Kestane (Chestnut) & 257,765 \\
\hline Kuşdili (biberiye) (Rosmarinus officinalis) & 247,500 \\
\hline Yosun, (Moss) & 168,964 \\
\hline Çalba (Ballota cristata, B, Saxatilis) & 129,588 \\
\hline Reçine, (Resin) & 120,937 \\
\hline Tavşanmemesi, (Ruscus aculeatus) & 89,306 \\
\hline Siklamen, (Cyclamen cilicium,C,coum, C, Hederefolum) & 76,106 \\
\hline Erika (funda-kök), (Erica arborea, ling-root) & 49,602 \\
\hline Lavanta, (Lavandula officinalis) & 48,250 \\
\hline Orman gülü, (Rhododendron) & 47,769 \\
\hline Eğrelti otu, (Dryopteris) & 38,542 \\
\hline Göl soğanı, (Leucojum aestivum) & 36,834 \\
\hline Sarmaşı, (Hedera helix) & 30,503 \\
\hline Ihlamur çiçeği ve yaprağı (Tilia sp.) & 30,259 \\
\hline Kardelen soğanı, (Galanthus elwasii, galanthus woronowii) & 28,283 \\
\hline Şimşir (dal ve sürgün), (Buxus sempenvirens, faggot and shoot) & 26,840 \\
\hline Göknar dall, (Fir faggot) & 23,630 \\
\hline Yoğurt çiçeği soğanı, (Anemone blanda) & 18,719 \\
\hline
\end{tabular}

(Kaynak: Orman Su, 2016'dan düzenlenmiştir.)

Çizelge 1'den de görüldüğü gibi, Defne Türkiye odun dışı orman ürünleri içerisinde önemli bir türdür. Odun üretimi sırasında değerlendirilmeden doğada bırakılan köklerin de, odun dışı orman ürünleri alanında önemli bir faydalanma fırsatı yarattığ görülmektedir. Kekik ve Fıstık çamı diğer dikkat çeken odun dışı ürünlerdendir. Çizelge 1'de gösterilmemiş fakat Türkiye Ormancılık İstatistiğinde (2016) yer alan 26 ayrı ürün daha bulunmaktadır. Çizelge 1'deki "çalılar" veya İstatistik yıllığındaki "mantarlar" ortak başlıklarının pek çok türü topladığı dikkate alındığında, Türkiye'deki çeşitliğin daha da artacağı açıtır. Nitekim OGM'nin bir başka yayınında Türkiye'de Ayı mantarı, Meşe mantarı, Kanlıca mantarı, Kuzu göbeği mantarı ve Domalan mantarından yararlanıldığı, bu mantarlara ek olarak yılda 388000 ton farklı mantarlardan üretim yapılabileceği belirtilmektedir (OGM, 2004). İlginçtir ki, OGM 2004'de yer alan bazı türler 2016 istatistiklerinde yer almamıştır.

Ülkenin odun dışı orman ürünü durumunu değerlendirirken ürün sayısı ve miktarı kadar, bu ürünleri veren türlerin doğadaki paylarının da bilinmesi yararlıdır. Çizelge 2'den de görüldüğü gibi, 1988-2016 dönemi için hesaplanan ortalama değerlerle, tahmin edilen üretim potansiyelleri arasında farklılıklar bulunmaktadır. Örneğin, 19882016 döneminde 7,8 ton $\mathrm{yll}^{-1}$ Defne üretimi gerçekleşmişken, bu tür için tahmin edilen kapasite 12,2 ton $\mathrm{yll}^{-1}$ düzeyindedir.

Manisa Akhisar bölgesinde tarımı yapılan bir tür halini alan Kekik'te de tahmin edilen üretim gerçekleşenin altındadır. 
Çizelge 2: Türkiye'deki Bazı Odun Dışı Orman Ürünlerinin Yayılış Alanları ve Tahmin Edilen Üretimleri

\begin{tabular}{|c|c|c|c|}
\hline Yararlanılan Türler & $\begin{array}{l}\text { Yararlanılan } \\
\text { Parcaları }\end{array}$ & $\begin{array}{l}\text { Yayılıs } \\
\text { Alanı (ha) }\end{array}$ & $\begin{array}{l}\text { Tahmin Edilen Üretim } \\
\text { Potansiyeli }\end{array}$ \\
\hline Defne (Laurus nobilis) & Yaprak ve tohum & 131.862 & $12.201 .326 \mathrm{Kg} \mathrm{yll}^{-1}$ \\
\hline $\begin{array}{l}\text { Kekik (Thymus serpyllum L. Thymus vulgaris } \\
\text { L. Thymus capitatus L.Thymbrae spicata L. } \\
\text { Origanum onites) }\end{array}$ & Çiçek ve dal & 602.683 & $5.241 .458 \mathrm{Kg} \mathrm{yll}^{-1}$ \\
\hline Fıstıkçamı (Pinus Pinea L.) & \begin{tabular}{|l|} 
Tohum, Kabuk, \\
Reçine, Kozalak
\end{tabular} & 65.914 & 2.545.064 Ton yll ${ }^{-1}$ \\
\hline $\begin{array}{l}\text { Adaçayı (Salvia officinalis L.Salvia cretica } \\
\text { L.Salvia triloba L.Salvia sclareae L.) }\end{array}$ & Yaprak & 193.726 & $1.247 .761 \mathrm{Kg} \mathrm{yll}^{-1}$ \\
\hline Laden (Cistus) & Dal ve yaprak & 208.359 & $116.336 .931 \mathrm{Kg} \mathrm{y1l}^{-1}$ \\
\hline Keçiboynuzu, Harnup (Ceratonia Siliqua L) & Meyve ve tohum & 21.816 & 554.350 Ton yll $^{-1}$ \\
\hline Kestane (Castanea vulgaris) & $\begin{array}{l}\text { Meyve, yaprak ve } \\
\text { kabuk }\end{array}$ & 109.270 & $6.647 .415 \mathrm{Kg} \mathrm{yll}^{-1}$ \\
\hline Biberiye (Rosmarinus officinalis L.) & $\begin{array}{|lll|}\begin{array}{l}\text { Ciçekli } \\
\text { ibreler }\end{array} & \text { dal } & \text { ve } \\
\end{array}$ & 10.118 & 4.038.323 Ton yll ${ }^{-1}$ \\
\hline $\begin{array}{l}\text { Yosun (Homolothecium sericeum, Gimmina } \\
\text { oxalis, Picramun scoparium) }\end{array}$ & Bütün & 50.323 & $783.650 \mathrm{Kg} \mathrm{yll}^{-1}$ \\
\hline Çalba (Ballota cristata, Ballota saxatilis) & Bütün & 62.639 & 813.500 Ton $\mathrm{yll}^{-1}$ \\
\hline Tavşan memesi (Ruscus acilaetus) & Çiçekli dal ve rizöm & 4.585 & 204.700 Ton yll $^{-1}$ \\
\hline
\end{tabular}

Kaynak: (OGM, 2004)

Ormancılık istatistiklerinin yıllar itibariyle içerdiği odun dışı orman ürünü bilgisi artmaktadır. Her yıl daha fazla türe ve ürüne yönelik bilgilerin kayda geçtiği görülmektedir. Hal böyle olmasına rağmen, tutulan istatistiklerin odun dışı orman ürünleriyle ilgili yaşanan değişimleri yansitmakta istenen yeterliliğe eriştiği düşünülmemektedir. Aynı türün farklı parçalarının farklı amaçlarla kullanılabildiği veya fiili kullanımların resmiyet kazanmadığı için istatistiklere yansımadığ $\breve{g}_{1}$ bilinmektedir. Örneğin, Ok ve ark. (2012) İstanbul çiçekçilerinin $175.238,7$ balya $\mathrm{yll}^{-1}\left(1.434,58\right.$ ton yll $\left.^{-1}\right)$ düzeyinde kocayemiş (Arbutus unedo) ve $164.968,3{\text { balya } \text { yll }^{-1}}^{(1.136,65}$ ton yll $\left.{ }^{-1}\right)$ Şimşir (Buxus sempenvirens) sürgünü tükettiğini tahmin etmişken, Çizelge 1'de Şimşirin tüm ülkede 26.840 ton $\mathrm{yll}^{-1}$ tüketildiği rapor edilmektedir. Kocayemiş tüketimine yönelik bir bilgi ise Çizelge 1'de bulunamamıştır. $\mathrm{Bu}$ nedenle, Türkiye'nin zengin biyolojik çeşitliliğinin yarattığı geniş odun dışı orman ürünü kullanım firsatı, bu alandaki yönetimi daha karmaşı bir hale getirmekte, ülkenin sorumluluklarını artırmaktadır.

Odun dışı orman ürünlerinin 1988-2016 dönemindeki yönelimi incelendiğinde, kök odunlarının istikrarsız üretime örnek olduğu görülmektedir (Şekil 1).

Kestane üretimi son yıllarda bir artış gösterse de, (Şekil 2) düzenli olarak arttığını söylemek güçtür. Son yıllarda Kestane ağaçlarında gözlenen kurumalara rağmen bir artışın olması ilginçtir. Kültüre alınıp tarımsal üretimi de yapılan Kekik (Şekil 2) dalgalı bir yapı göstermektedir. 1994 ve 2007 yıllarında aşırı Kekik üretimi görülürken, 2013 yılında bir dip son iki yıl yine azalış gözlenmiştir. Doğal ortamlardan gelen Kekik ile tarımsal faaliyetlerle üretilen kekiğin ayrı ayrı ve ilişkili izlenmesi, ekonomik ve sosyal boyutlarının yönetiminde önemli görünmektedir. Keçiboynuzu (harnup) üretiminin bir artış eğiliminde olduğu, Adaçayı ve Laden üretimlerinin mevcut durumu korudukları (Şekil 2) görülmektedir.

Türkiye odun dışı orman ürünleri üretiminde en hissedilir artış Defne üretimindedir (Şekil 3). 2013 yılındaki rekor düşüş dışında Defne istikrarlı bir şekilde artış gösterebilmiştir. Fıstıkçamı kozalağı ve iç fıstık üretimi uzun dönemde artı̧̧ eğilimi gösteren bir diğer üründür (Şekil 3). Fıstık kozalağı üretiminde 2011 sonrası gözlenen düşüşlerin nasıl bir sonuç vereceği, Fıstık çamlarında gözlenen böcek zararının bu türün ve ürünlerinin geleceğini nasıl etkileyeceği henüz bilinmemektedir. Pazar ve taleple ilgili değişkenler de üretim isteğini etkilemektedir. Bu durum odun dışı orman ürünleri yönetimindeki değişken sayısını artırmakta ve daha karmaşık ilişkilerin analizini gerektirmektedir.

\section{Odun Dışı Orman Ürünleriyle İlgili Türkiye'deki} Kurumsal Yapı

Türkiye ormanlarındaki odun dışı orman ürünlerinin yönetiminden, Orman ve Su İşleri Bakanlığına bağlı, Orman Genel Müdürlüğü (OGM) sorumludur. Türkiye'de, odun dışı orman ürünleri genellikle ormanlarda yetişmekte ve ormanların \% 99'u devletin mülkiyeti altında bulunmaktadır. 


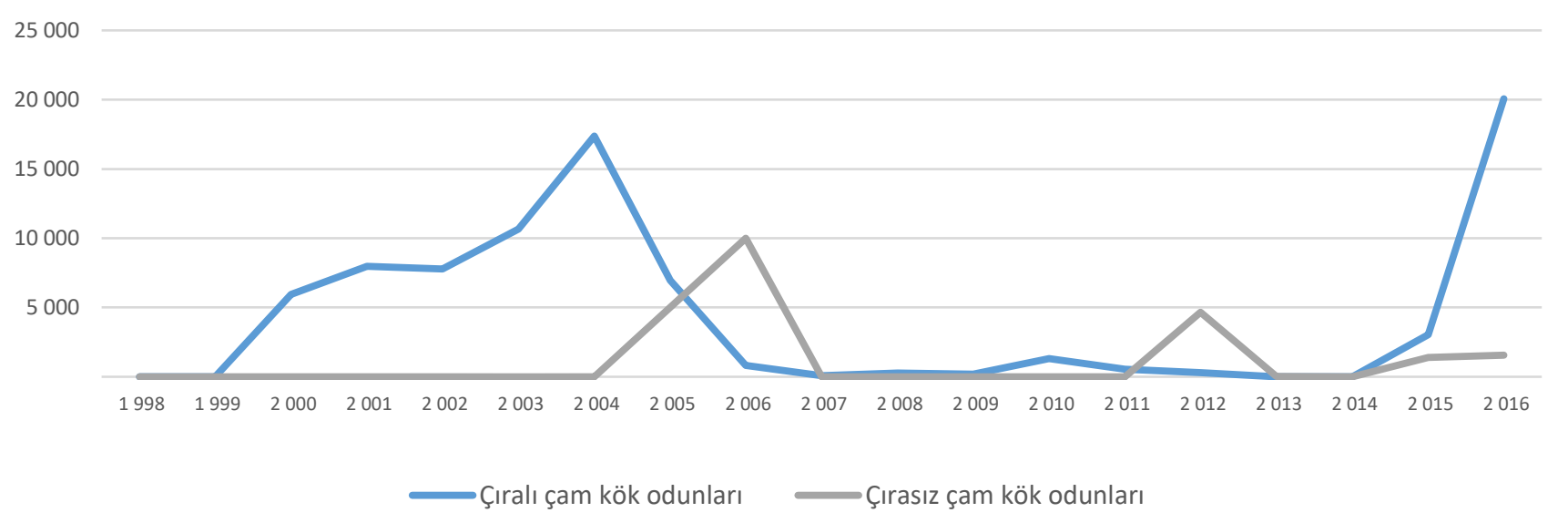

Şekil 1: Kök odunları üretimindeki değişim (Ton yıl-1)

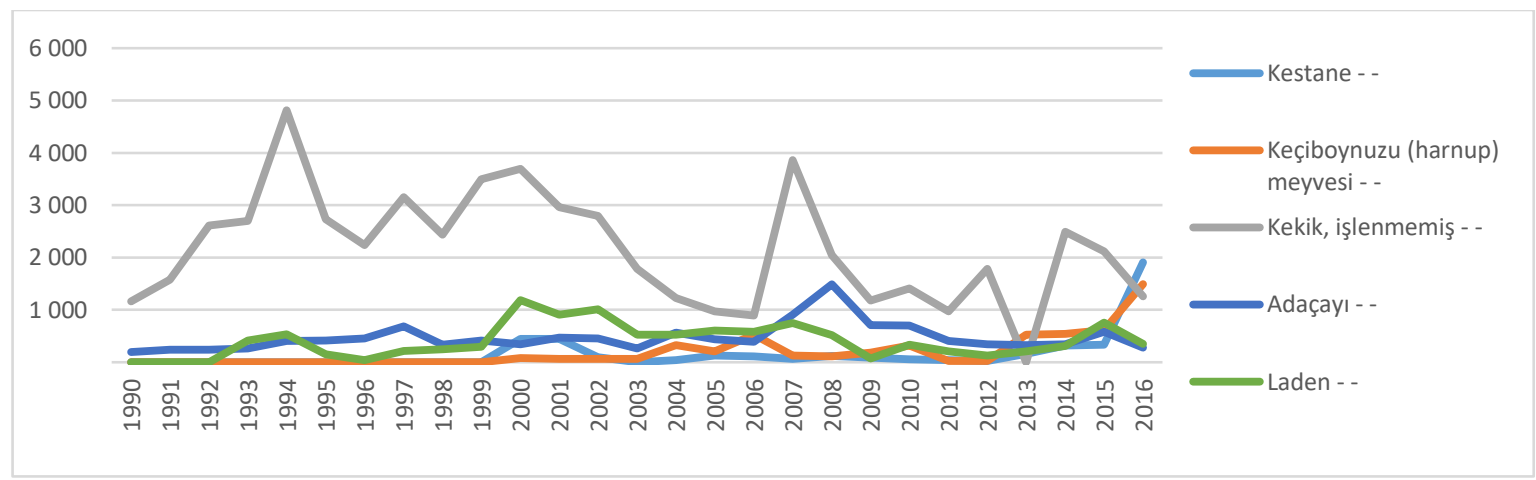

Şekil 2: Kestane, Keçiboynuzu, Kekik, Adaçayı ve Laden üretim yönelimleri

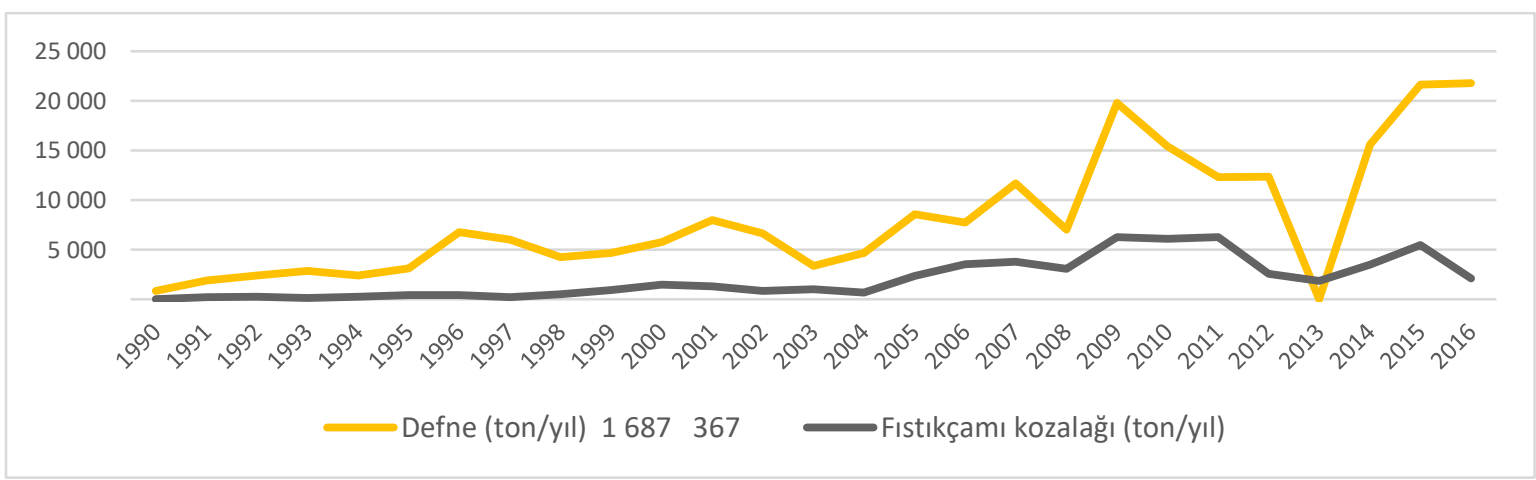

Şekil 3: Defne ve Fıstıkçamı Kozalağı üretim yönelimleri

3234 sayılı kanuna göre OGM "Ormanları, devamlılı̆̆ını sağlayacak şekilde, teknik ve ekonomik icaplara göre idare etmek ve işletmek, asli ve tali orman ürünlerinin; üretim, taşıma, depolama, iş ve işlemlerini yapmak ve yaptırmak, bu ürünleri yurt içinde ve dışında pazarlamak, ormancılık hizmetleri ile ilgili gerekli araç ve gereçleri temin ve tedarik etmek" görevindedir.

OGM'nin kurulduğu 1937 yılından, 2011 yılında 645 sayılı Kanun Hükmünde Kararname ile 3234 sayılı kanun ve ormancılık örgüt yapı değiştirilene kadar, odun dışı ürün veya kaynaklar "tali ürün" olarak kabul edilmiştir. 2011 yılında ise OGM içerisinde “ Odun Dışı Ürün ve Hizmetler Dairesi Başkanlığı" kurulmuştur. Odun Dışı Ürün ve Hizmetler Dairesi Başkanlığı'nın görevleri;

a) Odun dışı orman ürünlerinin ve ormanın ekosistem hizmetlerinin; envanteri, değer tespiti, teşhis, tanıtım, planlama, haritalandırma, projelendirme, üretim, taşıma, depolama ve pazarlanmasına ait iş ve işlemleri belirlemek, yapmak veya yaptırmak,

b) Orman içi su kaynaklarını korumak, geliştirmek, bu alanlarda yapılacak faaliyetleri düzenlemek, orman içi 
av ve yaban hayatına, otlatmaya, arıcılığa ait konuları takip etmek,

c) Uygun yerlerde eko-turizm faaliyetlerini desteklemek,

c) Mesire yerlerinin, kent ormanlarının ve ağaç parkı sahalarının ayrılması, korunması, işletilmesi ve işlettirilmesini sağlamak,

d) Genel Müdürlükçe verilecek benzeri görevleri yapmak şeklinde belirlenmiştir.

Şekil 4'den de görüldüğü gibi, Türkiye odun dışı orman ürünlerinin yönetimi, bakanlık ve OGM çatısı altında, Odun Dışı Ürün ve Hizmetler Daire Başkanlığı ve yedi ayrı şube müdürlüğü tarafından yönetilmektedir.

Şekil 4'deki yapı odun dışı orman ürünleriyle ilgili merkezi örgüt oluştururken, OGM'ye bağlı 28 Orman Bölge Müdürlüğünün örgüt yapısı içerisinde Odun Dışı
Ürün ve Hizmetler Şube Müdürlüğü kurulmuş olup, sorumlu taşra teşkilatını oluşturmaktadır. Yerelde hizmet veren Odun Dışı Ürün ve Hizmetler Şube Müdürlüğü'nün görevleri; Odun dişı orman ürünlerinin ve ormanın ekosistem hizmetlerinin; envanteri, değer tespiti, teşhis, tanıtım, planlama, haritalandırma, projelendirme, üretim, taşıma, depolama ve pazarlanmasına ait iş ve işlemleri belirlemek, yapmak veya yaptırmak, Orman içi su kaynaklarını korumak, geliştirmek, bu alanlarda yapılacak faaliyetleri düzenlemek, orman içi av ve yaban hayatına, otlatmaya, arıcılığa ait konuları takip etmek, Uygun yerlerde ekoturizm faaliyetlerini desteklemek, Mesire yerlerinin, kent ormanlarının ve ağaç parkı sahalarının ayrılması, korunması, işletilmesi ve işlettirilmesini sağlamak ve Bölge müdürünün vereceği benzeri görevleri yapmaktır.

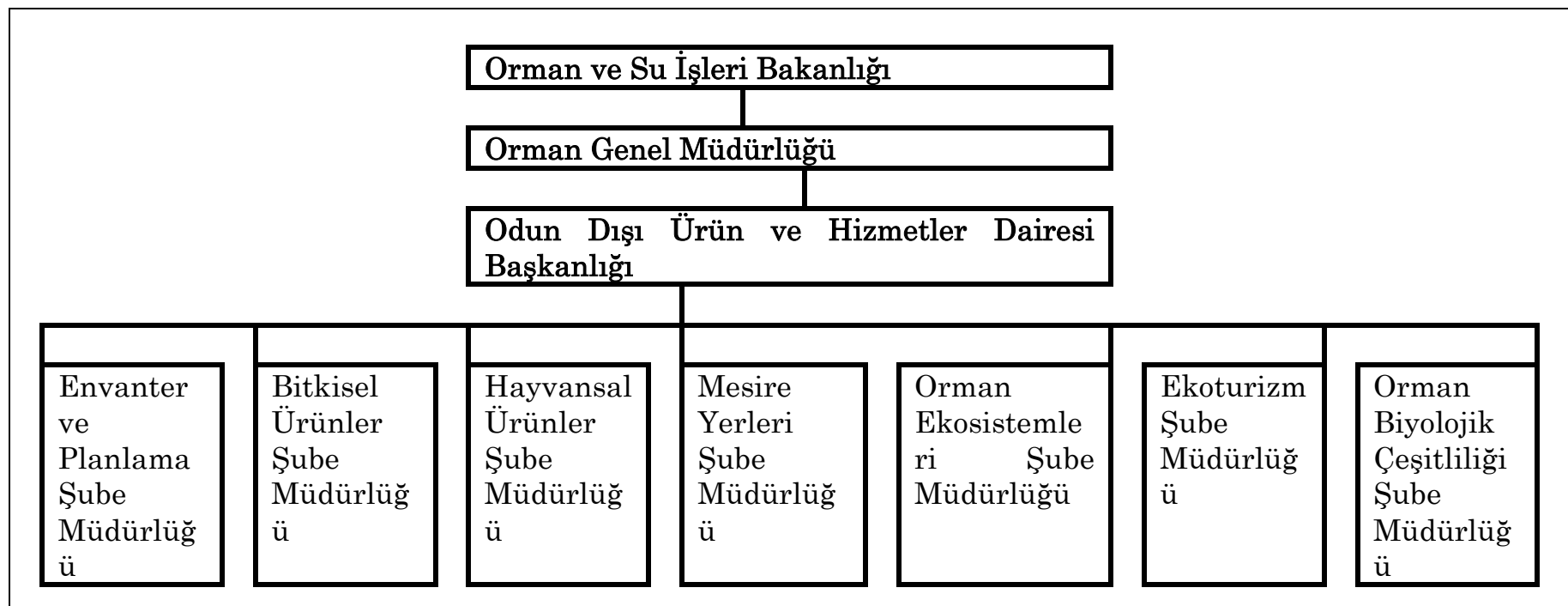

Şekil 4: Odun Dışı Ürün ve Hizmetler Dairesi Başkanlığğ Örgütsel Yapısı

\section{Odun Dışı Orman Ürünleriyle İlgili Türkiye'deki Kurumsal Anlayış}

Kurumsal yapıdaki değişimden de anlaşılacağı gibi, Türkiye'de odun dışı orman ürünlerine bakış zamanla değişmektedir. Bu değişimin, kurumsal yapıya ek bir diğer göstergesi, mevzuat içerisinde odun dışı orman ürünü hakkında yapılan tanımlamalardır. OGM, kuruluş kanununa ek olarak, 6831 sayılı Orman Kanunu, bu kanunla ilişkili olarak çıkarılan yönetmelik, tamim ve tebliğlere uygun çalışmak zorunda olan bir kamu kurumudur. Bu nedenle, odun dışı orman ürünlerinin yönetme şeklinin ve anlayışının bir göstergesi olarak, ilgili mevzuat incelenmelidir. Ancak bu incelemeyi, Odun Dışı Ürün ve Hizmetler Dairesi Başkanlığı'nın kurulduğu 2011 yılı öncesi ve sonrası için ayrı ayrı yapmak değişimi görebilmek için gereklidir.

Odun Dışı Ürün ve Hizmetler Dairesi Başkanlığı öncesinde, OGM'nin odun dışı ürünlerle ilgili çalışmaları 1995 yılında kabul edilen 283 numaralı Orman Tali Ürünlerinin Üretim ve Satış Esasları
Tebliği'ne göre yürütülmüştür. Bu tebliğe göre “ $B a z ı$ orman ağaç ve ăgaççılarının gövdelerine tekniğine uygun metotla yara açmak suretiyle elde olunan reçine, sı̆̆la yă̆g vs. gibi balsamı yağlar, Defne, Okaliptüs vs. gibi ăgaç ve ăgaççkların yaprakları, Mazı, Palamut, Sumak, Defne, Mahlep, Menengic, Cam fistı̆̆g gibi meyveler, bazı ağaç ve ağaç̧̧ıların gövde kabukları, ince dal ve sürgünleri ile gerek orman altı florayı teşkil eden gerekse orman rejimine giren sahalarda yayılış gösteren Kekik, Adaçayı, Kartal ĕgreltisi, Nane, Pelin otu, Hardal vs. gibi ağaç̧ık, çalı, çalımsı görünüssteki bitkiler ile otsu, rizomlu, yumrulu ve soğanlı bitkiler orman tali ürünleri” olarak adlandırılır. Bu tanıma göre, odun dışı orman ürünü denildiğinde, OGM'nin bitkisel kökenli ürünleri anladığı, halen odunu asli, odun dışı ürünleri ise tali şeklinde bir ayrıma tabi tutarak, dünyadaki kavramsal gelişimlerin gerisinde kaldığı söylenebilir. İlk bakışta, tüm orman ürünlerine yönelik hazırlandığı yönünde bir algı oluşturmasına rağmen, 1996 yılında çıkarılan 289 sayılı "Orman Ürünlerinden 
Faydalanmak İsteyenlere Verilecek İzinlere Ait Tebliğ" de odun dışı ürünlere kavramsal bakışın bir göstergesidir. $\mathrm{Bu}$ tebliğde orman ürünleri "her çeşit ăgaç, ăgaçıık, mantar, tıbbi ve sınai bitkiler ile bunlardan elde edilen kök, fidan, kozalak tohumu, kabuk, meyve, çiçek, ibre, yaprak, dal, sürgün, yumru, soğan, çıra, katran, sakız, mazı, balzam, ur ve benzerleri' şeklinde tanımlanmış ve esasen odun dışı bitkisel orman ürünleri belirtilmiştir.

OGM'deki odun dışı orman ürünü anlayışın değiştiğinin bir başka kanıtı, 2013 yılında, 297 sayılı Odun Dışı Orman Ürünlerinin Envanter ve Planlaması İle Üretim ve Satış Esasları isimli tebliğin yayınlanmasıdır. 297 sayılı tebliğge göre Odun dışı orman ürünleri: "Ormanlardan elde edilen odun dışındaki tüm bitkisel ve hayvansal ürünler ile mantarları ifade etmekte, endüstriyel odun üretimi esnasında açı̆̆a çıkan ă̆aç kabukları, kozalaklar, çalılar, yongalar, kökler ile mantarlar, orman humusu ve örtüsü de aynı grupta yer almaktadır".

297 sayılı tebliğin yaptığı tanımdan da anlaşıldığı gibi; Türkiye, sadece bitkisel kökenli ürünleri odun dışı ürün olarak gören anlayışını, hayvansal ürünlerle, üretim $\operatorname{artığ~} 1$ kabul edilen, kozalak, kök, orman humusu gibi değerlere doğru genişletmiştir.

Bununla birlikte, anlayış değişiminini temsil edebilen tebliğlerin 2016 yılında bir defa daha yenilendiği görülmektedir. 2016 yılında OGM, 302 sayll "Odun Dışı Orman Ürünlerinin Envanter ve Planlaması İle Üretim ve Satış Esasları" isimli tebliği yayınlamıştır. 302 sayılı tebliğe göre odun dışı orman ürünü denildiğinde "ormanlardan ve ağaçlardan elde edilen odun dıșındaki biyolojik ve mineral kökenli ürünler ile kabuk, yonga, çall, kök, kütük, kozalak gibi odun üretimi sırasında açı̆̆a çıkan diğer ürünler ile mantarlar, orman humusu ve örtüsü' anlaşllmaktadır. Aradan sadece üç yıl geçmesine rağmen, 297 sayılı tebliğde, hayvansal ürünler odun dışı orman ürünleri içerisinde kabul edilirken, 302 sayılı tebliğ ile kapsam dışında itildiği, bir başka değişle, tekrar bitkisel üretimi temel alan bir anlayışa dönüldüğü görülmektedir.

Türkiye Ulusal Ormancılık Programında Odun Dışı Orman Ürünleri

Türkiye, 2004 - 2023 yılları için Ulusal Ormancılık Programı hazırlamıştır. Ulusal Ormancılık Programları FAO'nun dünya ülkelerini hazırlamaya teşvik ettiği önemli belgelerdir. Katılımcı bir anlayışla hazırlanan bu program, ne yazık ki, bakanlar kurulu kararı ile ormancılık kurumları için bağlayıcılığı olan bir belgeye dönüştürülmemiş fakat ormancılık sektörünün farklı noktalara bakışının sağlam bir göstergesi olmuştur.

Ulusal Ormancılık Programının ülke ormancılığının mevcut durumunu irdeleyen bölümünde, "Odun Dוşו Orman Ürünleri Faydalanması ve Odun dıșı orman ürünlerinden faydalanma” (ÇOB, 2004) şeklinde iki özel başlık görülmektedir. Bu başlıklar incelendiğinde var olan potansiyelin vurgulandığı, bu kaynaklardan faydalanmanın sürdürülebilirliği konusunda kaygıların ön plana çıkarıldığı görülmektedir.

Ulusal Ormancılık Programına göre ormancılığın; Ormanların Korunması, Ormanların Geliştirilmesi ve Orman kaynaklarından faydalanma şeklinde üç ana amacı bulunmaktadır. Ormanların korunması amacının içerisinde "Orman köylülerinin odun ve odun dışı orman ürünleri ihtiyaçlarının, ormanların kapasitesi dahilinde yasal yollardan mümkün olduğunca karşılanması, orman köylülerinin ormanların odun dışı ürün ve hizmetlerinden faydalanma ve gelir elde etme imkanlarının geliştirilmesi” (ÇOB 2004) şeklinde bir politikaya yer verilmiştir. $\mathrm{Bu}$ politika odun dışı orman kaynakları konusunda üç stratejiye yer vermiştir. Bu stratejiler;

Strateji IV. Ormanların biyotik ve abiyotik zararlara (yangın, kaçak odun kesimi, odun dışı orman ürünleri kaynaklarından düzensiz yararlanmalar, düzensiz / aşırı otlatma, açma / yerleşme, böcek, mantar ve diğer hastalıklar, hava kirliliği, vb.) karşı korunması alanlarında orman teskilatınin kurumsal kapasitesinin ve bu çalışmalara ayrılan kaynakların güçlendirilmesi,

Strateji V. Ormanlardan gizli/kaçak odun ve odun dıșı ürün faydalanmalarının azaltılması ve verdiğg zararlarının önlenmesi için: (i) orman yönetim ve faydalanma planlarının hazırlanması sirasında, yerel köylülerin odun ve odun dışı orman ürünleri ihtiyaçlarının belirlenmesi ve ormanların kapasitesi dahilinde yasal yollardan karşılanmasının geliştirilmesi, bu ürünlerin indirimli fiyatlarla karşılanmasının sürdürülmesi; (ii) orman köylerinde odun tüketiminde tasarruf sağlayıcı tedbirlerin ve alternatif enerji kaynaklarının kullanımının yayginlaştırılması,

Strateji VI. Orman köylülerin yörelerindeki ormanların yönetim kararlarına katılımının ve orman kaynaklarının işlevsel (çok amaçlı) yönetiminin geliştirilmesi. Orman köylülerinin ormanların odun dıș ürün ve hizmetlerinin (yem, tıbbi-aromatik bitkiler, meyve, mantar, su kaynakları, rekreasyon, av-yaban hayatı, avcılık, vb.) gelir potansiyellerinden yararlanmalarının artırılması için uygun modellerin ve gerekli tedbirlerin orman tesskilatı, yerel halk ve diğer ilgi grupları işbirliği ile yürütülecek çalışmalarla (pilot projeler, araștırma, mevzuat ve kurumsal gelişme, vb.) geliştirilmesi ve uygulamalarının yaygınlaştırılması, şeklinde ifade edilmiştir (ÇOB 2004).

Ulusal Ormancılık Programının ikinci amacı ormanların geliştirilmesiyle ilgilidir. $\mathrm{Bu}$ amaç kapsamında yer alan "mevcut ormanların geliștirilmesi" politikası, odun dışı orman ürünlerinin geliştirilmesiyle ilgili olarak " $V$. Orman köyleri yakınındaki ağaçlandırma ve imar çalışmaları 
sirasinda uygun alanlarda, yerel halkın odun ve odun dışı orman ürünlerine olan ihtiyaçlarını karşılamaya ve gelir imkanları yaratmaya uygun orman ağaç, ağaçıık ve diğer bitki türlerinin kullanılmasına, uygun silvopastoral uygulamalara ve yerel halkın bu çalışmalara katılımlarının desteklenmesine ve güçlendirilmesine özen gösterilmesi" (ÇOB, 2004) şeklinde bir stratejiye yer vermektedir.

Orman kaynaklarından faydalanma konusunda ayrılan üçüncü amaç içerisinde odun dışı orman ürünlerinin daha yoğun ele alındığı anlaşılmaktadır. Nitekim bu amacın içerdiği iki ayrı politikayla ilişkilendirilebilecek dört ayrı strateji bulunmaktadır. Ulusal Ormancılık Programında amaçlar ve stratejiler yanında, politika ve eylemlere de yer verilmiştir. Faydalanma konusundaki amacın içerdiği politikalarının ilkinde "ii. Ormanların odun dışı ürün kaynaklarının sürdürülebilir yönetimi ve faydalanması suretiyle toplumun odun dışı orman ürünleri ihtiyaç ve taleplerinin, yerel ve ülkesel düzeylerde optimum şekilde karşılanmasi" hedeflenirken, ikinci politikada bu işin daha çok uygulama aşaması dikkate alınmakta ve "iii. Odun ve odun dışı orman ürünlerinde standardizasyon ve sertifikalandırma sisteminin; ulusal koşullar ve uluslararası gelişmeler dikkate alınarak belli bir süreç içinde geliştirilmesi, uygulamaların yaygınlaştırılması. Odun dıșı orman ürünlerinin dış ticaretinin disipline edilmesi, Bu ürünlerin hammadde yerine mamul madde olarak ihracatını teşvik etmeye yönelik tedbirlerin gerçekleştirilmesı" şeklinde bir politika ifadesine yer verilmektedir. Bu iki politikayla ilgili olarak benimsenen stratejiler ise;

Strateji V. Ormanlarda odun dışı ürünlerden (tıbbi ve aromatik bitkiler, hayvan yemi, su, meyve, mantar, vb.) faydalanmanın önemi konusunda orman teşkilatı ve yerel halk arasında bilinçlenme ve ilginin artırılması. Havza bazında entegre ve katılımcı olarak hazırlanacak yönetim planlarında odun dışı ürünü faydalanmasına ayrılacak sahaların, ayrıntılı yönetim planlarının/projelerinin (koruma, geliştirme, faydalanma esaslarını ve faaliyetlerini belirleyen) yerel halkın katılımı ile hazırlanması ve uygulanması konularinda bilgi, deneyim ve metodolojilerin geliştirilmesi, orman teşkilatının kurumsal kapasitelerin güçlendirilmesi, ilgili mevzuatın geliştirilmesi,

Strateji VI. Orman köylülerinin odun dışı ürünlerinin üretimi, istihsali, işlenmesi, pazarlanması konularında bilgi ve deneyimlerin artırılması ve kapasitelerinin güçlendirilmesine yönelik eğitim ve destek programlarının orman teşkilatı, yerel halk, bilim kuruluşları, özel sektör, sivil toplum kuruluşları ve diğer ilgi grupları işbirliği ile geliştirilmesi ve sürdürülmesi,

Strateji VIII. Odun dışı ürünlerinin dış ticaretinin disipline edilmesi. Bu ürünlerin hammadde yerine mamul madde olarak ihracatını teşvik etmeye yönelik mevzuat ve kurumsal gelişme tedbirlerinin gerçekleştirilmesi şeklindedir (ÇOB, 2004).

Ulusal Ormancılı Programının Faydalanma amacı kapsamında kalan "Yerel haklara sayg1, orman köylülerinin yaşam şartlarının iyileştirilmesine ve yoksulluğun azaltılmasına katkı" politikası da odun dışı orman ürünleriyle ilişkilidir. Nitekim bu politikanın içerdiği stratejiler içerisinde "iii. Orman köylülerinin ve örgütlerinin, ormanların ürünlerinden ve hizmetlerinden (odun ve odun diș orman ürünlerinin yetiştirilmesi, hasadl, işlenmesi, pazarlanması, küçük su kaynaklarından faydalanma, uygun alanlarda çok amaçlı ağaçlandırmalar, hayvan yemi faydalanması, silvapastoral uygulamalar, ekoturizm, köy avlakları, balıkçılık, vb.) faydalanma kapasitelerinin güçlendirilmesine yönelik çalışmaların (ĕgitim, pilot çalışmalar, finans desteği, vb.), orman köy örgütleri, orman teşkilatı, sivil toplum örgütleri ve diğer ilgili kuruluşların ortak ve eşgüdümlü çalışmaları ile gerçekleştirilmesi” (ÇOB, 2004) şeklinde bir strateji yer almış ve yerel halkların haklarıyla odun dışı ürünler yakın bir şekilde irtibatlandırılmıştır.

Ulusal Ormancılık Programında odun dışı orman ürünüyle ilgili sadece politika ve stratejilere yer verilmemiş, bu kapsamda eylemler (19, 24, 99, 100, $101,102,105,106,107,108$ ve 131 numaralı) de önerilerek, ilgili kurumlar sorumlu hale getirilmiştir. Toplam 11 eylemden 4 tanesi Orman ve $\mathrm{Su}$ İşleri Bakanlığı merkez birimlerinin uygulama sorumluluğuna bırakıldığı, diğerlerinden OGM'nin sorumlu tutulduğu görülmektedir.

Orman Genel Müdürlüğü Stratejik Planlarında Odun Dışı Orman Ürünleri

OGM, 5018 sayılı Kamu Mali Yönetimi ve Kontrol Kanunu gereği, stratejik plan hazırlamak zorunda olan kurumlar arasındadır ve stratejik planında belirtilen amaç ve hedefler doğrultusunda eylemlerini yürütmesi yasa gereğidir. Stratejik Planda yer alan amaç, hedef, strateji ve performans göstergeleri, OGM'nin kurumsal anlayışını kanıtladığından bu çalışmada odun dışı orman ürünlerinin son üç stratejik planındaki yeri incelenmiştir.

Incelenen ilk stratejik plan 2010-2014 yılları için hazırlanan plandır. Bu planda OGM'nin "Ormanların ürettiği mal ve hizmetlerden toplumun gelişen ve değişen beklentilerini en üst düzeyde karşılamak, ormanlardan çok yönlü ve sürdürülebilir şekilde faydalanmak" amacının bir parçası olarak, Hedef 3.6.'da "Odun d1şı orman ürünlerinin potansiyeli tespit edilerek, faydalanma düzenlenecek ve plan döneminde ekonomik öneme sahip odun dışı ürün çeşit ve miktarı $\% 25$ oranında artırılacaktır" (OGM, 2009) denilmektedir.

Planın odun dışı orman ürünleriyle ilgili açıklamaları incelendiğinde, esasen 283 ve 289 sayılı tebliğdeki 
odun dışı orman ürünü tanımının benimsendiği görülmektedir. Henüz odun dışı bu alanda bir daire başkanlığının kurulmamış olduğu bir döneme rastladığ $\breve{1}_{1}$ hatırlandığında, OGM'nin kavramsal bakışıyla plandaki anlayışının uyumlu olduğu görülmektedir.

Planda Hedef 3.6 ile ilgili özel stratejiler tanımlanmamış fakat "üretilen veya toplanan bu ürünlerin ormanllk alanlardaki potansiyelinin belirlenmesi, biyolojik çeşitliliğin tespit edilmesi, korunması ve geliştirilmesi, erken toplamaların, kalite kayıplarının ve assırı toplamaların önlenmesi ile bu türlerin devamlılı̆̆gnın sağlanması için gerekli tedbirlerin alınması ve sürdürülebilir faydalanmanın sağlanması, gen kaynaklarının korunması gerekmektedir (OGM, 2009)" denilerek, süreklilik kaygıları ifade edilmiştir. Bir önlem olarak "Plan döneminde; odun d1şı orman ürünlerinin üretimi, islenmesi, pazarlanması konularında orman köylülerinin bilgi ve deneyimlerinin artırılması ve kapasitelerinin güçlendirilmesine yönelik eğitim ve destek programları geliştirilerek sürdürülecektir" denilerek, sürdürülebilirliğin sosyal boyutu dikkate alınmıştır.

$\mathrm{Bu}$ plan döneminin odun dışı orman ürünleri yönetimiyle ilişkili olarak gerçekleştirmek istediği eylemleri; "ormanlardan toplanan ürünlerin sıkı takip ve kontrollerinin yapılması, bu ürünlerin tür ve miktarının belirlenebilmesi için istatistiki bilgi ve verilerin oluşturulması, envanter metotları ve planlama tekniklerinin belirlenmesi, ülke içi tüketimin saptanması, ihracatı yapılabilecek yeni ürünlerin araştırılması, faydalanmanın devamlılı̆̆ için türleri geliştirme ve yetiştirme olanaklarının araştırılması, yarı mamul veya mamul olarak işlenmesi ve sanayinin geliştirilmesi ve yerel ekonomiye katkı sağlaması imkanlarının araştırılması, yararlanılan türlerin koruması ve gelişimlerinin izlenmesi için izleme metotlarının geliştirilmesi" (OGM, 2009) şeklinde ifade ettiği ve öncelikli alt hedefler olarak belirttiği görülmektedir.

2010-2014 plan döneminde OGM'nin odun dışı orman ürünleri alanındaki faaliyetlerini toplam odun dışı orman ürünü çeşidi ve sayısı (adet), odun dışı orman ürünlerinin değerlendirme şekli ve miktarı (ton) ile ticarete konu odun dışı orman ürünü çeşit sayısı ve miktarı (adet ton ${ }^{-1}$ ) göstergeleriyle (OGM, 2009) izlemeye karar verdiği görülmektedir.

İncelenen ikinci stratejik plan; 2013-2017 yılları için hazırlanmıştır. OGM bünyesinde odun dışı orman ürünleri alanında özel bir daire başkanlığının kurulmasından sonra hazırlandığı için,

2013-2014 planında bu konu daha fazla yer bulmuştur. Planın genel bilgiler kısmında odun dışı orman ürünleri kapasitesine yönelik daha ayrıntılı bilgiler verilmiş, ülkenin sahip olduğu biyolojik çeşitliliğin bu alanda bir kapasite sunduğu, ihraç olanaklarıyla dış ticarette üstünlükler sağladığı, kırsal fakirlik açısından değerlendirilebilecek imkânlar sunduğu belirtilmiştir. Yapılan durum analizinde ise OGM'nin zayıf yönleri veya geliştirmesi gereken alanlar listesinde "Odun dışı ürün ve hizmetlerin yeterince değerlendirilememesi” (OGM, 2012) şeklinde bir saptama yer almıştır. OGM'nin dış ortamı analiz edilirken, odun dışı orman ürünleri alanında "Orman yangınları, orman suçları ve odun dışı orman ürün kaynaklarından düzensiz ve tahrip edici yararlanmaların azalarak da olsa halen var olmasi" (OGM, 2012) kurumsal bir tehdit olarak belirlenmiştir.

2013-2017 Stratejik Planında “Orman köylülerinin odun ve odun dlşı orman ürünleri ihtiyaçlarının, ormanların kapasitesi dâhilinde karşılanması, orman köylülerinin ormanların odun dışı ürün ve hizmetlerinden faydalanma ve gelir elde etme imkânlarının geliştirilmesi' OGM'nin temel stratejisi olarak ifade edilmiştir (OGM, 2012). Odun Dışı Orman Ürünleri Dairesi; Stratejik Planın özellikle 1. (Ormanları, orman sayılan yerleri ve bu yerlerdeki biyolojik çeşitliliği, her türlü biyotik ve abiyotik zararlılara karşı korumak) ve 3. (ormanların ürettiği mal ve hizmetlerden toplumun gelişen ve değişen beklentilerini en üst düzeyde karşılamak, ormanlardan çok yönlü ve sürdürülebilir şekilde faydalanmak) amaçları içerisinde yer alan Hedef 1.5., 3.4. ve 3.7'den sorumlu tutulmuştur.

Stratejik planın birinci amacı, aslında doğrudan odun dışı orman ürünlerine yönelik olmasa da, özünde odun dışı orman ürünlerinin dayandığı biyolojik çeşitlilik ve süreklilik kaygılarına yöneliktir. $\mathrm{Bu}$ kapsamda oluşturulan Hedef 1.5'de "Orman alanlarındaki biyoçeşitlilik tespitleri yapılacak, biyoçeşitlilik bir fonksiyon olarak amenajman planlarına entegre edilecek, bu alanlar düzenli olarak izlenecek ve korunmasi gerekenler koruma altına alınacaktır" denilerek, planlama metodolojisi açısından doğru bir yaklaşım benimsenmiştir. Bu hedefle ilgili olarak hazırlanan yedi strateji incelendiğinde; biyolojik çeşitliliğin kırsal fakirlikle ilişkisinden, farkındalık yaratmaya, envanter ve planlamadan izleme ve değerlendirmeye, korunan alan ayırımından korunan alan dişındaki ormanlarda biyolojik çeşitliliğin korunmasına, işbirliği yapılacak kurumlara kadar uzanan geniş bir ilgi alanını kapsadığı fakat odun dışı orman ürünleri kelimesinin doğrudan kullanılmadığ görülmektedir. Planda, belirtilen tüm stratejilerin biyoçeşitlilik envanteri yapılan orman alanı (ha) göstergesi ile izlenebileceği düşünülmüştür.

2013-2017 planının üçüncü amacının 3.4. numaralı hedefi, odun dışı orman ürünlerine açıkça yer veren bir hedeftir. Bu hedef "Odun dişı orman ürünlerinin potansiyeli tespit edilerek, faydalanma düzenlenecek ve plan döneminde ekonomik öneme sahip ürün çeşit 
ve miktarı \% 25 oranında artırılacaktır" şeklinde ifade edilmiş olup, aslında bir önceki planda da var olan bir hedeftir. Bir başka değişle, OGM bu hedefini değiştirmeye gerek görmeden, uygulamakta israr etmiştir.

Hedef 1.5'de olduğu gibi, 3.4 numaralı hedef için de beş ayrı temel strateji belirlenmiştir. Her biri odun dışı orman ürünlerine yönelik olan bu stratejiler;

- Ormanların odun dişı ürün kaynaklarının sürdürülebilir yönetimi ve faydalanması suretiyle toplumun odun dişı orman ürünleri ihtiyaç ve taleplerinin optimum şekilde karşılanması,

- Odun dışı orman ürünlerinde standardizasyon ve sertifikalandirma sisteminin; ulusal koşullar ve uluslararası gelişmeler dikkate alınarak belli bir süreç içinde gelisstirilmesi, uygulamaların yayginlaştırılması,

- Odun dışı orman ürünlerinin dış ticaretinin disipline edilmesi, bu ürünlerin hammadde yerine mamul madde olarak ihracatını teşvik etmeye yönelik tedbirlerin alınması,

- Orman köylülerinin odun dışı orman ürünlerinin üretimi, istihsali, işlenmesi, pazarlanması konularında bilgi ve deneyimlerin artırılması ve kapasitelerinin güçlendirilmesi, yeni bilgi, deneyim ve metodolojilerin geliștirilmesi, orman tesskilatının kurumsal kapasitesinin güçlendirilmesi, ilgili mevzuatın geliştirilmesi,

- Odun dışı orman ürünlerinden faydalanmaya yönelik takip ve kontrollerin artırılması şeklindedir (OGM, 2012).

Yukarıda belirtilen temel stratejilerin izleme ve değerlendirilmesinde; Odun dışı orman ürünleri envanteri yapılan alan miktarı (ha) ve değerlendirilen odun dışı orman ürünü (ton) şeklinde iki ayrı performans göstergesinin yeterli olacağı düşülmüsstür.

Odun Dışı Ürün ve Hizmetler Dairesi'nin sorumluluğuna verilmiş bir diğer hedef yine üçüncü amaç kapsamında ve 3.7 numarasiyla oluşturulmuştur. Hedef 3.7'de "Ormanların sosyal, kültürel, bilimsel, sportif ve estetik hizmetlerinden toplumun daha fazla faydalanmasinın sağlanması yönünde rekreasyon alanları belirlenecek, hizmet seviyesi ve kalite artırılacaktır" denilmektedir. Hedef içeriğinin bitkisel ürünlerden çok, ekoturizm ve rekreasyon temelli hizmetlere yönelik olduğu görülmektedir. Her ne kadar bu hedeften Odun Dışı Ürün ve Hizmetler Dairesi sorumlu birim olarak gösterilmişse de, OGM'nin 283 ve 289 sayılı tebliğindeki odun dışı ürün tanımı hatırlandığında, bu hizmetler odun dışı ürün ve hizmet olarak kabul edilmemiştir. Bir başka değişle, OGM tebliğlerinde yaptığg tanımdan daha geniş bir kabule göre birimleri arası iş bölümü yapmak durumunda kalmıştır.

Buraya kadar açıklanan amaç ve hedefler, 2013-2017 planında doğrudan Odun Dışı Ürün ve Hizmetler
Dairesi'nin sorumluluğuna verilmiştir. Ancak, planın ikinci (Mevcut ormanların geliştirilmesi ve verimliliğinin artırılması ile uygun arazilerde yeni ormanlar kurularak orman alanlarının genisletilmesi) ve dördüncü (sürdürülebilir orman yönetimini sağlamaya, daha hızlı ve kaliteli hizmet sunmaya, belirlenen stratejik amaçlara ulaşmaya yönelik kurumsal gelişimi sağlamak) amacı içerisinde de bu dairenin sorumluluklarıyla ilişkili iki ayrı hedef bulunmaktadır.

Ormanların geliştirilmesi şeklindeki ikinci amacın 2.2. numaralı hedefini (Verimli orman alanı 12500000 hektara çıkarılacaktır) de odun dışı orman ürünleriyle ilişkili düşünmek gereklidir. Nitekim bu hedefin açıklamalarında "bozuk orman alanlarındaki zengin odun dișı orman ürünleri potansiyelinin ekosistem dengesi içerisinde korunması, değerlendirilmesinde köy tüzel kişiliklerine öncelik verilmesi ve bu hususta ilgili resmi ve sivil kurumlarin desteklerinin sağlanmasına çalışılacaktır" denilerek, odun dışı ürünlerle ilişki açıkça ifade edilmiştir.

Planın kurumsal kapasiteyle ilgili dördüncü ve son amacinın 4.1. numaralı hedefi ARGE ihtiyacı ile ilgilidir. Yapılan açıklamalardan bu hedefin içeriğinden ne anlaşıldığı görülmekte ve Ormancılık Araştırma Enstitüsü Müdürlüklerinin odun dışı orman ürünleri alanında da araştırma projeleri yaptığg ve yapması beklendiği ortaya çıkmaktadır.

2013-2017 planında OGM'nin bir süredir üzerinde çalıştığı sürdürülebilir orman yönetimi çalışmalarında kurumsal olarak kabul ettiği kriter setine de yer verilmiştir. Stratejik plan hiyerarşisi içerisinde, böylesi bir bilginin gerekli olup olmadığı tartışılabilir olsa da, verilen setin içerisinde yer alan Kriter 4, ormanların üretim kapasitesi ve fonksiyonları başlığını taşımakta ve 4.4. numaralı alt başlığında "Odun dışı orman ürünleri üretimi" alt ölçütüne yer verilmektedir. Ormanların Sosyo Ekonomik Fonksiyonları isimli 6 numaralı kriterin ikinci (6.2.) alt başlığı da "Odun dışı orman ürünlerinin değeri" konusuna ayrılmıştır. Bu nedenle OGM'nin stratejik planında da ifade ederek, sürdürülebilir orman yönetimi anlayışının odun dışı orman ürünlerini de kapsayan bir bakışa sahip olduğunu kanıtladığı söylenebilir.

İncelenen son stratejik plan OGM'nin halen geçerli stratejik planıdır ve 2017-2021 yılları için hazırlanmıştır. $\mathrm{Bu}$ planda, OGM birimleri bazı hedeflerden doğrudan sorumlu tutulmuşken, bazılarında işbirliği yapacak birim olarak gösterilmiştir. Odun Dışı Ürün ve Hizmetler Dairesi planın üçüncü amacının 3.3. numaralı hedefinden sorumlu tutulmuşken, Amaç 1'in 1.2 ve 1.4, Amaç 2'nin 2.1, Amaç 3'ün 3.1 ve Amaç 4'ün 4.1, 4.2 ve 4.3 numaralı hedeflerinde işbirliği yapılacak birim olarak gösterilmiştir. 2017-2021 planının içerdiği amaçlar aslında bir önceki planın içerdiği amaçlarla aynıdır. 
Ancak güncel planda amaç kelimesi yerine gaye kelimesinin kullanılması tercih edilmiştir.

Odun Dışı Ürün ve Hizmetler Dairesinin sorumluluğuna verilen tek hedef olan Hedef (H3.3) "Rekreasyon hizmetleri yayginlaştırılacak, odun diș orman ürünlerinin potansiyeli belirlenerek ekonomik öneme sahip ürün çeşidi \% 10, üretim miktarı ise \% 75 oranında artırılacaktır" şeklindedir. Bu hedefin önceki iki plan hedefleriyle karşılaştırılmasından, OGM'nin bir anlayış değişimine gitmek zorunda kaldığı görülmektedir. Bu değişimin; yararlanılan türlerin \% 25 artırılması anlayışının \% 10'a indirilmesi ve üretim miktarlarına özel bir nicel hedefin konması noktalarında olduğu söylenebilir.

OGM, hedef 3.3 ile ilgili üç ayrı temel strateji belirlemiştir. Bu Temel stratejiler (OGM 2016);

- Rekreasyon hizmetlerine yönelik toplumsal taleplerin karşılanması ve rekreasyon alanlarında hizmet çeşitlilï̆ginin artırılması,

- Odun dışı orman ürünlerine yönelik bilinç ve farkındalığın artırılması,

- Envanter ve planlama çalışmalarında istihdam edilecek personelin deneyim kazanması, uzmanlaşması gayesiyle uygun istihdam politikaların gelişstirilmesi şeklindedir.

Hedef 3.3. kapsamında belirlenen stratejikleri izlemek ve değerlendirmek için toplam beş adet performans göstergesi oluşturulmuştur. Bu göstergelerden ilk ikisi rekreasyonel hizmetlerle ilgilidir. Odun dişı orman ürünleriyle ilgili olarak; odun dışı orman ürün envanter ve planlaması yapılan alan (ha), değerlendirilen yıllık odun dışı orman ürünü miktarı (ton) ve ekonomik öneme sahip ürün çeşidi (adet) göstergeleri oluşturulmuştur.

Önceki planda olduğu gibi, 2017-2021 planında da sürdürülebilir orman yönetim ölçütlerine yer verilmiştir. Odun dışı orman ürünleri, önceki plandaki yerini koruyarak, aynen bu planda da sürdürülebilir orman yönetimi içerisinde kendine yer bulmuştur.

\section{Türkiye'de Odun Dışı Orman Ürünlerinden Faydalanma Planları}

Türkiye ormanlardan faydalanma konusunda mevzuatı ve gelenekleri olan bir ülkedir. 6831 sayılı Orman Kanununun 26. Maddesi "Orman insan ilişsilerinde, ormanın korunması, kullanma değerlerinin esas tutulması, ormancılıkta ve amenajman planlarında çok taraflı faydalanma esaslarını getirmek maksadiyla; Devlet ormanlarından yapılacak istihsal, Tarım ve Orman Bakanliğnca tespit olunacak esaslar dairesinde ve amenajman planlarına göre Devlet tarafindan yapılır veya 40. madde hükümleri dairesinde yaptırılabilir" hükmü ile faydalanmayı amenajman planlarına bağlamıştır. Bu maddede devlet ormanlarından söz edilse de, adı geçen kanunun 46. Maddesinde kamu ormanları, 51. Maddesinde ise özel ormanlarda da Orman Amenajman Planlarına göre yararlanma yapılabileceği belirtilmektedir. Bu nedenle, ister odun hammaddesi ister odun dişı orman ürünleri söz konusu olsun, orman amenajman planlariyla süreklilik önlemleri alınmamış bir yararlanma, yasal olarak olanaksızdır. OGM içerisinde Orman İdaresi ve Planlama Daire Başkanlığı orman amenajman planlarının hazırlanmasından, özel ormanlar için hazırlanan planların denetlenmesinden sorumludur.

Bununla birlikte, orman amenajman planları genellikle odun hammaddesini planlamaya odaklanmıştır. Amenajman planlarının hazırlanma esaslarını açıklayan yönetmeliklerin oduna odaklandığı, odun dışı orman ürünleri ile diğer ormancılık hizmetlerinin nasıl planlanacağ konusunda yol gösterici hükümler içermediği görülmüştür. Özellikle doksanlı yıllarda bu konu oldukça eleştirilmiş ve OGM, 2008 yılında amenajman planları hazırlama anlayışını değiştiren bir düzenleme yapmış ve yeni bir Orman Amenajman Yönetmeliği yayınlamıştır. OGM'ye göre bu yönetmelik ekosistem tabanlı, çok amaçlı ve fonksiyonel planlama anlayışına göre planlar yapmaya uygun bir yönetmeliktir.

2008 tarihli Orman Amenajman Yönetmeliğinde amenajman "bir orman işletmesini veya onun ayrıldi ̆̆ alt işletme ünitelerini tespit edilen amaçlara göre planlayan ve planin uygulanmasinı izleyen bir ormancılık bilim dali" (OGM, 2008) şeklinde tanımlanmıştır. Bilindiği gibi odun dışı orman ürünü üretmek de bir ormancılık amacıdır ve bazı orman parçaları bu amaçla yönetilmektedir. Yönetmeliğin amenajman tanımına göre bu alanlar için de bir amenajman planı hazırlanmalıdır.

Nitekim bu anlayışa uygun olarak Orman Amenajman Yönetmeliğinin farklı maddelerinde odun dışı orman ürünlerinden söz edilmekte, envanterinin nasıl yapılacağı açıklanmakta, hatta çıkarıldığı dönemdeki kurumsal odun dışı ürün anlayışına paralel olarak, hayvansal, mineral kökenli odun dışı ürünlerden ve envanterinden söz edilmektedir. 76. Maddesinde ise "Ana amacı odun dışı orman ürünleri, defne yapră̆ı, reçine, sığla yă̆g, kabuk, tohum, meyve ve benzeri gibi üretimi olan orman alanlarında planlama, her ürünün yetiştirme ve ormandan çıkarma yöntemlerinin gerektirdiği özel durumlara uygun olarak yapılır. Bu ürünlerin üretim planlanması, diğer fonksiyonlarla kombine edilerek yapılır. Odun dışı orman ürünlerinin üretilmesinde, küresel ve ulusal süreçlere uygun, yasal düzenlemeler de dikkate alınarak hareket edilir. Gereğinde, özel üretim planları düzenlenir” denilerek, odun dışı orman ürünlerinin de odun üretim planlarıyla bütünleşik fakat bu alana özel planlarla yönetileceği ifade edilmektedir.

Hal böyleyken, 2011 yılında OGM örgüt yapısının değiştirilmesinin, odun dışı orman ürünlerinden yararlanmanın planlanması konusunda kurumsal 
anlayış ayrılığına neden olduğu görülmektedir. Odun Dışı Ürün ve Hizmetler Dairesi'nin kurulmasının da etkisiyle olsa gerek, odun dışı orman ürünleriyle ilgili tebliğlerin içeriği değişmeye başlamıştır. 2011 öncesi odun dışı orman ürünleri tebliğleri incelendiğinde, (283 sayll Orman Tali Ürünlerinin Üretim ve Satış Esasları Teblï̆i, 289 sayll Orman Ürünlerinden Faydalanmak Isteyenlere Verilecek İzinlere Ait Tebliğ) izin verme ve satış işlemini yönetme konularına odaklanıldığı görülmektedir. Oysa sonraki tebliğlerde (297 sayılı Odun Dışı Orman Ürünlerinin Envanter ve Planlaması Ile Üretim ve Satış Esasları, 302 sayılı Odun Dişı Orman Ürünlerinin Envanter ve Planlaması Ile Üretim ve Satış Esasları) envanter ve planlama konuları da kapsam alanına alınmıştır. Bu tebliğleri destekleyecek şekilde Odun Dışı Ürün ve Hizmetler Yönetim Planı dispozisyonları hazırlanmış, planların nasıl yapılacağı, tıpkı amenajman yönetmeliğinde olduğu gibi açıklanmaya çalışılmıştır.

OGM'nin stratejik planlarında odun dışı orman ürünlerinin yeri açıklanırken ".. biyoçeşitlilik bir fonksiyon olarak amenajman planlarına entegre edilecek, bu alanlar düzenli olarak izlenecek ve korunmasi gerekenler koruma altına alnacaktır" ifadelerinin hedef 1.5 'de geçtiği belirtilmiştir. Odun dışı orman ürünlerinin odun üretim alanlarından bağımsız veya biyolojik çeşitlilikle ilişkilendirilmeden yönetilemeyeceği açıktır. $\mathrm{Bu}$ nedenle, biyolojik çeşitlilikle orman amenajmanını bütünleştirmeye çalışan ama odun dışı orman ürünlerinin yönetimi ile bütünleşme kaygısı gütmeyen bir yapı ortaya çıkmış durumdadır. Halen orman yönetim planları ile odun dışı orman ürün ve hizmetleri yönetim planlarının hangi noktalarda birleştiği, hangi noktalarda ayrıştığı, birbirini tamamlayan yönlerinin ne olduğu bilinmemektedir.

\section{TARTIŞMA, SONUÇ VE ÖNERİLER}

Dünya'nın pek çok ülkesinde olduğu gibi, Türkiye'de de odun dışı orman kaynaklarına bakış zamanla gelişmektedir. Türkiye'deki ilerleyişin dünyadaki anlayışa paralel geliştiği fakat henüz arzu edilen düzeye gelinemediği söylenebilir. Bu ürünlerle ilgili süreklilik kaygıları Türkiye'de ve dünyada (Sunderland, Ndoye, 2017) devam etmektedir.

Şüphesiz odun dışı orman ürünlerinin kapsamını sadece bitkisel kökenli ürünlerle sinırlı tutmak veya hayvani ve mineral kökenli ürünlerle farklı hizmetlere doğru genişletmek de düşünülebilir. Ancak bu genişlemenin getireceği faydalar ve sakıncaları da dikkate almak gereklidir. Bir bitki bazen meyvesiyle bazen kabuğuyla değer yaratırken, hizmet de üretebilmektedir (Tomé, Faias, 2014). Sadece meyvenin üretiminin planlanmasında; meyve ile ilgili hava hallerinden, olgunlaşma zamanına kadar değişen pek çok değişkeni dikkate almak gerekirken, kabuğun da bir ürün olarak değerlendirilmesi halinde, birim zamanda gelişen kabuk miktarından, hasat edilen kabuk miktarı ile bitkinin yaşamını sürdürebilirliği arasındaki ilişkiye kadar çeşitlenen yeni değişkenler işin içerisine girmektedir. Bu nedenle, planlamanın dikkate alması gereken değişken sayısı, odun dışı ürün veya kaynaktan ne anlaşıldığına göre değişir. Odun dışı kaynakları bitkilerden hayvanlara, minerallerden hizmetlere doğru genişletmek planlama modellerinin içermesi gereken değişken sayısını artırmakta, ilişkileri karmaşıklaştırmaktadır. O nedenle, kavramların yönetilebilir bir içerikte tutulması daha anlamlı bir yaklaşımdır. OGM'nin önce bitkiselden hayvan ve mineralleri de kapsayan geniş bir bakışa geçiş yapması, ardından bitkisel içerikle sınırlı daha dar bir içeriğe dönmesi aslında, uygulamada da bu karmaşanın görüldüğünün bir kanıtı olabilir.

Odun dışı orman ürünlerini yönetmek, bu alanda istatistik tutmakla sınırlı bir çaba değildir. İstatistik tutmak gereklidir ama yönetsel hedeflere hizmet edebilecek şekilde istatistik tutulmalıdır. Stratejik planların içerdiği performans göstergeleri aslında hangi değişkenlerle ilgilenildiğini, hangi konularda istatistik tutmak gerektiğini kanitlamaktadır. Türkiye'deki durum incelendiğinde, henüz yararlanılan tür sayısı, elde edilen ihracat geliri, planı yapılabilen alan büyüklüğü gibi değişkenlerle ilgilenildiği görülmektedir. Sürdürülebilir bir odun dışı kaynak yönetimi isteniyorsa, yararlanılan bitkinin biyolojisiyle ilgili, ilişkili toplumsal kesimlerin sosyal yapısını tanımlayabilen, kullanılan ve elde edilen ekonomik kaynakları ifade edebilen değişkenlerin de izlenmesi, performans göstergesi haline getirilmesi gereklidir.

Ulusal Ormancılık Programındaki odun dışı kaynaklarla ilgili politika, strateji ve eylem önerilerinin bir bütün olarak ele alınmasından da görüleceği gibi, Türkiye ormancılığı bir yandan bu kaynaklardan yararlanmak isterken, diğer yandan süreklilikleri hakkında kaygılar taşımaktadır. Bu ürünler ile ilgili bilgi eksiklikleri gerek Ulusal Ormancılık Programı gerek OGM stratejik plan ifadelerinden rahatlıkla görülebilmektedir. Ulusal Ormancılık Programı'nda odun dışı orman ürünleri üretiminin sosyal ve toplumsal boyutlarının farkında olunduğunu kanıtlayan ifadeler yer almaktadır. Ulusal Ormancılık Programı'nın odun dışı kaynakların sürekliliğini sağlamak için gerekli ekolojik, ekonomik ve sosyal boyutları dikkate almaya çalıştığı söylenebilir. Buna rağmen, 2011 yılında Odun Dışı Ürün ve Hizmetler Dairesi Başkanlığı'nın kurulmasının, 297 ve 302 sayılı tebliğlerin yayınlanmasının Ulusal Ormancılık Programı ve OGM Stratejik Plan hedeflerinden ne kadarını karşılayabildiği tartışılmalıdır. Meksika örneğinde (Delgado ve ark. 2016) görüldüğü gibi, Türkiye'de de odun dışı ürünlerle ilgili kurumsal bir farkındalığın 
oluştuğu ancak pratiği yönlendirebilecek yetkinliğe henüz erişilemediği görülmektedir.

Yetiştirme çalışmalarını dışlayarak, ürünlerin hasat edilmesine odaklanmış bir üretim anlayışıyla tebliğlerin hazırlandığı anlaşılmaktadır. Nasıl ki bir odun hammaddesinin üretimi denildiğinde, kesime olgun hale gelmiş bir ağacin hasatiyla yetinilemeyeceği, bu ağacın olgun hale gelene kadar yapılması gereken, dikim veya gençleştirme, bakım, koruma ve en sonunda hasat işlerini kapsayan bir anlayışın uygulanması gerekiyorsa, odun dışı ürünlerde de daha geniş üretim bakışına sahip olunmalı, Tomé, Faias, (2014) örneğinde görüldüğü gibi, türe ve ürüne özel kılavuzların hazırlanması gereklidir. Doğanın ektiği veya diktiği, doğal süreç içerisinde kendi halinde gelişmiş bir bitkinin envanterini yapıp hasatını gerçekleştirmek üretimin sadece son adımlarına odaklanmak demektir. Oysa bir bitkinin sürekliliği için insan veya doğanın o bitkiyi orman ortamlarına nasıl getireceği (dikerek, ekerek vb.), hasata olgun hale gelene kadar doğal veya insan kaynaklı zararlara karşı kim tarafından korunacağı, süreklilik için önemli kararlardır ve bu kararları içermeyen bir üretim anlayışı eksiktir. Bu nedenle, hazırlanan tebliğlerin; ilgilenilen tür ve ürüne özgü kararları, bitkinin toprakla buluşmasından kesilerek veya sökülerek ayrılmasına kadar geçen tüm süreci kapsayacak bir anlayışla geliştirilmesi, bunun için gerekli biyolojik ve teknik bilgi eksikliklerinin acilen araştırılması gereklidir.

Bir orman alanının bir parçası odun hammaddesi üretirken, hemen yanı odun dışı kaynaklar barındırıyor olabilir. Hatta ve hatta aynı orman parçası bir yandan odun hammaddesi üretirken diğer yandan odun dışı değerlere kaynaklık yapabilir. $\mathrm{Bu}$ gibi durumlarda odunu planlayan birim olan Orman İdaresi ve Planlama Dairesi ile Odun Dışı Ürün ve Hizmetler Dairesi'nin işbirliği kaçınılmazdır. $\mathrm{Bu}$ işbirliğini kurabilmenin yolu ise Orman Amenajman Yönetmeliği ile Odun Dışı Ürün ve Hizmetler Yönetim Planları'na temel olan kurumsal kararların uyumunu sağlamaktan geçmektedir. Orman kaynaklarının planlanmasına aşamalı yaklaşım $(\mathrm{Ok}, 2000)$ bu noktada çözüm olabilecek bir bakıştır. Her düzeyde yönetsel karara yanıt verebilecek şekilde ve tek aşamada ormanların planlanabildiği iddiasından vaz geçilmelidir. Bir ormanın kim veya hangi uzmanlıklar tarafından ve nasıl; odun dışı orman ürünü üretimi, odun üretimi, su üretimi, .. vb. amaçlara tahsis edileceği mevzuat içerisinde açıklanmalı, bu karara bağlı olarak tanımlanmış alanda odun dışı orman ürünlerinin nasıl planlanacağı ayrıca açıklanmalıdır. OGM'nin stratejik planında ifade edilen biyolojik çeşitliliğin amenajman planlarıyla bütünleştirilmesi hedefi, Altunel'in (2011) belirtiğine göre orman işletme şeflerinin beklentilerine de uygundur. Ormanlar için ayrı, odun dışı ürünler için ayrı yönetim planları hazırlamak ve bu sorumluluğu iş yükleri oldukça fazla orman işletme şeflerine yüklemek yerine, ülke orman planlama sistematiği içerisinde ve orman amenajman planlarıyla bütünleşebilen bir yapı kurmak amaçlanmalıdır.

\section{TEŞEKKÜR}

20-23 Eylül 2017 tarihlerinde Kırgızistan, Bişkek’te yapılan Avrasya Tarım ve Doğa Bilimleri Kongresinde sunulan ve İngilizce özeti yayınlanmış bildirinin tam metnidir.

\section{KAYNAKLAR}

Altunel, A., T., 2011: Odun Dışı Orman Ürünlerinin Dünyada ve Türkiye'de Sosyoekonomik Boyutu, İÜ Fen Bil. Ens. Or. Ekonomisi Programı, Basılmamış Doktora Tezi, 220 sayfa.

Başkent, E., Z., Küçüker, D., M., 2011: Inventory of Non Wood Forest Products, Proceedings of II. International Non-wood Forest Products Symposium, 8-10 September 2011. Isparta. ISBN:978-9944-452-52-6. Pages: 58-67.

Berkes, F., Davidson - Hunt, I., 2010: Innovating through commons use: community-based enterprises, International Journal of the Commons, Vol. 4, no 1 February 2010, pp. 1-7.

Bozkurt, Y., Yaltırık, F., Özdönmez M., 1982: Türkiye'de Orman Yan Ürünleri, İ.Ü. Yayın No: 2845, OF. Yayın No: 302, İstanbul. 190 sayfa.

Chamberlain, J. L., 2004: A Strategy for Nontimber Forest Products Research and Technology Transfer for Southern United States, Proceedings of the IUFRO Division 5 Research Groups 5.11 and 5.12, New Zealand, march 11-15, 2003. USDA, PNW GTR 604.

ÇOB 2004: Türkiye Ulusal Ormancılık Programı 20042023. Ankara

Davidson-Hunt., I., Duchesne L., C., Zasada J., C., 2001: Nontimber Forest Products: Local Livelihoods and Integrated Forest Management, (İcinde Forest Communities in the Third Millennium: Linking Research, Business, and Policy Toward a Sustainable Non-Timber Forest Product Sector, USDA, GTR- NC- 217, 2001.

Delgado T., S., McCall, M., K., Binqüist, C., L., 2016: Recognized but not supported: Assessing the incorporation of non-timber forest products into Mexican forest policy, Forest Policy and Economics 71 (2016) 36-42

FAO 2016: State of the World's Forests 2016. Forests and agriculture: land-use challenges and opportunities. Rome. ISBN 978-92-5-109208-8.

Işık, K.,2014: Biyolojik Çeşitlilik, ANG Vakfı yayın no: 2, ISBN: 978-975-01176-0-2, İstanbul, 224 Sayfa.

Lund, H. Gyde. 1998: The non-wood forest resources mystery. In: Lund, H. Gyde; Pajari, Brita; Korhonen, Minna. eds. 1998. Sustainable 
development of non-wood goods and benefits from boreal and cold temperate forests. Proceedings of the workshop. Joensuu, Finland. 18-22 January 1998. EFI Proceedings 23. Joensuu, Finland: European Forest Institute; 29-45.

Lynch, K. A., Maclain, R., J., 2003: Access, Labour, and Wild Floral Greens Management in Western Washington's Forests, PNW-GTR-585. 61. Pages.

Mohammed, G. H., 2001: Recommendations for Sustainable Development of Non-timber Forest Products, (İçinde Forest Communities in the Third Millennium: Linking Research, Business, and Policy Toward a Sustainable Non-Timber Forest Product Sector, USDA, GTR- NC- 217, 2001.

Mukherjee S., Chaturvedi, S., S., 2017: Utilization Aspects of Floral Non-Timber Forest Products: A Review, Asian Journal of Multidisciplinary Studies, 5(4) April, ISSN: 2321-8819 (Online) 23487186 Vol. 5, Issue 4, April 2017.

Neves, A., C., O., Fazito, D., Fernandes, G., W., 2015: Revisiting The Paradigm and the Paradox of NonTimber Forest Products Harvest: Perspectives in the Context of Agriculture Expansion, Oecologia Australis, $\quad$ 18: 51-54, 2015, 10.4257/oeco.2014.18.08.07

OGM, 1987: Ülkemizdeki Bazı Önemli Orman Tali Ürünlerinin Teşhis ve Tanıtım Kılavuzu, Yayın No:659, Seri No: 18, 89 sayfa.

OGM, 2004: Türkiye Ormanlarında Odun Dışı Ürünler, Ankara.

OGM, 2008: Orman Amenajman Yönetmeliği, Ankara.

OGM, 2009: 2010-2014 Orman Genel Müdürlüğü Stratejik Plan, Ankara.

OGM, 2012: 2013-2017 Orman Genel Müdürlüğü Stratejik Plan, Ankara.

OGM, 2016: Stratejik Plan 2017 - 2021. https://www.ogm.gov.tr/ekutuphane/StratejikPlan/ Forms/AllItems.aspx (30.06.2017).

OGM, 2017: https://www.ogm.gov.tr/Baskanliklar/OdunDisiUr unveHizmetler/Sayfalar/Odun-Disi-Urun-veHizmetler.aspx (30.06.2017).

Ok K. 2000: Orman Kaynakları Planlamasına Aşamalı Yaklaşım. İ.Ü. Orman Fakültesi Dergisi Seri B Cilt 49 Sayı: 1-2-3-4 İstanbul.
Ok, K., Alagöz, G. Ö., Atıcı, E., Çoban, S., Şenyurt, M., 2012: Süsleme Amaçlı Kullanılan Odun dışı Orman Ürünlerinin Sürdürülebilir Yönetimi, TÜBİTAK 1090264 Proje Sonuç Raporu, DOI: 10.13140/RG.2.1.1019.9764, https://www. researchgate.net/publication/282845134

Orman Su, 2016: Ormancilık Istatistikleri 2016, https://www.ogm.gov.tr/ekutuphane/Istatistikler. 16-F6A1-40F4-BE44-7526AE967FDC\} (Erişim, 31.07.2017)

Shackleton, C., M., Pandey, A., K., 2014: Positioning non-timber forest products on the development agenda, Forest Policy and Economics 38 (2014) 1-7

Sisak, L., Riedl, M., Dudik, R., 2015: Non-market nontimber forest products in the Czech RepublicTheirsocio-economic effects and trends in forest land use, Land Use Policy 50 (2016) 390-398,

Sunderland T., C., H., Ndoye, O., 2017: Management and conservation of NWFP resources, (İçinde Living in and from the forests of Central Africa, 65-74, Food and Agriculture Organization of the United Nations (FAO), Non-Wood Forest Products no. 21, ISBN: 978-92-5-109489-1, ISSN: 1020-9727, Rome, Italy.

Tomé, M., Faias, S., P., 2014: State of the art, review of silviculture, models and decision support tools for multipurpose trees (MPT) and non-wood forest products (NWFP). Deliverable 2.1 of the StarTree Project.

Topay, M., 2011: Recreation as an Important Nonwood Forest Product, Proceedings of II. International Non-wood Forest Products Symposium, 8-10 September 2011. Isparta, ISBN:978-9944-452-52-6. Pages: 58-67.

Vance, N., C., Borsting, M., Pilz, D., Freed, J., 2001: Special Forest Products Species Information Guide for the Pacific North West, PNW-GTR-513. 169. Pages.

Vantomme, P., 2001: FAO's Non-wood Forest Products Programme, Seminar Proceedings of Harvesting of Non`wood Forest Products, 2-8 October 2000. Izmir. 